\section{ABSTRACT}

\title{
Evidence of Equilibrium Peak Runoff Rates in Steep Tropical Terrain on the Island of Dominica During Tropical Storm Erika, August 27, 2015
}

\author{
Fred L. Ogden, Ph.D., P.E., P.H., Professor \\ fogden@uwyo.edu
}

Tropical Storm Erika was a weakly organized tropical storm when its center of circulation passed more than $150 \mathrm{~km}$ north of the island of Dominica on August 27, 2015. Hurricane hunter flights had difficulty finding the center of circulation as the storm encountered a high shear environment. Satellite and radar observations showed gyres imbedded within the broader circulation. Radar observations from Guadeloupe show that one of these gyres formed in convergent mid-level flow triggered by orographic convection over the island of Dominica. Gauge-adjusted radar rainfall data indicated between 300 to $750 \mathrm{~mm}$ of rainfall on Dominica, most of it over a four hour period. The result was widespread flooding, destruction of property, and loss of life. The extremity of the rainfall on steep watersheds covered with shallow soils was hypothesized to result in near-equilibrium runoff conditions where peak runoff rates equal the watershed-average peak rainfall rate minus a small constant loss rate. Rain gauge adjusted radar rainfall estimates and indirect peak discharge (IPD) measurements from 16 rivers at watershed areas ranging from 0.9 to $31.4 \mathrm{~km}^{2}$ using the USGS Slope-Area method allowed testing of this hypothesis. IPD measurements were compared against the global envelope of maximum observed flood peaks versus drainage area and against simulations using the U.S. Army Corps of Engineers Gridded Surface/Subsurface Hydrologic Analysis (GSSHA) model to detect landslideaffected peak flows. Model parameter values were estimated from the literature. Reasonable 
agreement was found between GSSHA simulated peak flows and IPD measurements in some watersheds. Results showed that landslide dam failure affected peak flows in 5 of the 16 rivers, with peak flows significantly greater than the envelope curve values for the flood of record for

28 like-sized watersheds on the planet. GSSHA simulated peak discharges showed that the remaining 11 peak flow values were plausible. Simulations of an additional 24 watersheds ranging in size from 2.2 to $75.4 \mathrm{~km}^{2}$ provided confirmation that the IPD measurements varied from $40 \%$ to nearly $100 \%$ of the envelope curve value depending on storm-total rainfall. Results presented in this paper support the hypothesis that on average, the peak discharges scaled linearly with drainage area, and the constant of proportionality was equivalent to $134 \mathrm{~mm} \mathrm{~h}^{-1}$, or a unit discharge of $37.22 \mathrm{~m}^{3} \mathrm{~s}^{-1} \mathrm{~km}^{2}$. The results also indicate that after the available watershed storage was filled after approximately 450 to $500 \mathrm{~mm}$ of rain fell, runoff efficiencies exceeded 50 to 60 percent, and peak runoff rates were more than 80 percent of the peak rainfall rate minus a small constant loss rate of $20 \mathrm{~mm} \mathrm{~h}^{-1}$. These finding have important implications for design of resilient infrastructure, and means that rainfall rate was the primary determinant of peak flows once the available storage was filled in the absences of landslide dam failure.

\section{Introduction}

The 2015 tropical Atlantic hurricane season was quiet by most measures. However, one

42 particularly devastating counterpoint was the impact of Tropical Storm Erika on the island nation 43 of Dominica. Figure 1 shows the location of Dominica in the eastern Caribbean basin and the 44 approximate path of TS Erika. Even though the center of TS Erika passed more than $150 \mathrm{~km}$ 45 north of Dominica, the synoptic scale mid-level flow produced a region of significant 46 convergence in the vicinity of Dominica. Dominica's topography exerts a strong orographic 
47 control over rainfall (Smith et al., 2012), and the net effect of regional convergence with 48 topographic interactions on Dominica was over $500 \mathrm{~mm}$ of rainfall in 10 hours on 27 August, 492015.

\section{$<$ FIGURE 1>}

51 According to the U.S. National Weather Service, on August 27, 2015, the hurricane 52 reconnaissance flight from the U.S. had difficulty identifying the center of circulation. The 53 storm was located in a region of very high precipitable atmospheric water in excess of $60 \mathrm{~mm}$

54 (Votaw et al., 2015). The storm track was difficult to forecast because upper level wind shear 55 caused the predominance of convection to occur east of the center of circulation (Franklin, 56 2015).

When torrential rains fell in Dominica in the early morning hours of 27 August, 2015, most people were caught by surprise because forecasters did not predict significant weather from 59 TS Erika. The preceding two weeks were quite rainy, with about $200 \mathrm{~mm}$ of precipitation. 60 Unfortunately, Erika produced extreme rainfall that caused the most significant flooding in 61 Dominica since Hurricane David in 1979. There was significant loss of life, and damages to 62 structures near rivers. Many of the bridges on the island were damaged or destroyed. The entire 63 island was impacted except the far northwestern portion. TS Erika also produced significant 64 amounts of rainfall that caused damage in Puerto Rico and Hispanola on August 28.

65 Dominica has the most rugged topography of all the Caribbean islands. The island has 66 two main volcanoes that are both nearly $1,500 \mathrm{~m}$ in elevation, as well as ten smaller volcanoes.

67 This makes the topography of the island very steep as over 60 percent of the slopes on the island 68 are steeper than 30 percent gradient (World Bank 2004). As a result, most of the populated areas 69 lie on coastal alluvial fans, and most of the interior of the island is covered by forest that has re- 
grown since the massive destruction rendered by Hurricane David in 1979. Finally, the soils in Dominica are of volcanic origin and almost exclusively thin (Rouse et al., 1986). The relatively recent andesitic-dacitic eruptive history has created the condition where variations in rainfall amounts are the main determinant of soil type (Goldsmith et al., 2010) because of different weathering sequences. As a result there are four main clay-rich soil types on Dominica (Rouse et al., 1986). On the western coastal regions where there is a dry season the soils are montmorillonitic and smectitic. Rainforest areas that have a weak dry season have kaolinitic soils. The continuously wet regions on the north and eastern mountain flanks have allophanic latosols. In the highest elevation regions annual rainfall exceeds $7000 \mathrm{~mm}$ (Benson et al. 2001), and are dominated by allophone podzolics (Rouse et al., 1986). Rouse et al. (1986) found that the development of saturated soils that initiate landslides occurs during high-intensity rainfall associated with tropical cyclones.

This study was designed to test the hypothesis that the combination of high-intensity rainfall for several hours on small, steep, tropical catchments with uniform land cover and thin saprolitic soils led to runoff conditions that approached equilibrium. The word "equilibrium" is used here in the sense that the peak rate of watershed runoff was well approximated by the peak rate of rainfall input This hypothesis was tested using weather radar rainfall estimates, indirect peak discharge (IPD) measurements in 16 watersheds, and a two-dimensional process-based hydrological model. Results are compared against the envelope curve (Rodier and Roche, 1984; ICOLD, 2002) for global maximum flood peaks as a function of watershed area.

The lack of hydrometeorological data in tropical locations (Wohl et al., 2012), and particularly on small islands, limits the ability of engineers to adequately design resilient infrastructure. The development of meaningful rainfall and flood statistics for the Caribbean 
93 islands, particularly the lesser Antilles, is hampered by many sources of complexity (Lumbroso

94 et al. 2012). This storm, with extreme high-intensity rain falling for several hours, offered an

95 opportunity to evaluate flooding resulting from extreme rainfall in a tropical volcanic island 96 setting.

97 Landslides represent a complicating factor in analyses such as this one because they can 98 create dams that, when breached by overtopping or other failure mechanism, release a torrent of 99 water, increasing the flood peak beyond that which would have occurred had there not been a 100 landslide that formed a dam (Larsen, 2008). Dominica has the steepest topography on average of 101 any island in the Caribbean. This fact coupled with widespread thin soils that are prone to 102 saturation, causes many landslides during extreme rainfall events, and makes Dominica 103 extremely vulnerable to landslides (Costa and Schuster, 1988).

104 Most landslide dams are small and are overtopped during the rainfall event that caused 105 them. There have been exceptions (Arlington and Serrant, 1997) such as the event of November 106 18, 1997, when a landslide dam blocked the Layou River and failed after three days, released

107 large quantities of water. On November 25 of that same year, a much larger landslide occurred in 108 the same general area. Similarly this landslide dam also failed after three days and led to 109 catastrophic damages to crops and property along the Layou River. A secondary effect of this 110 large slide was the creation of a dam on the Matthieu River, which is a tributary to the Layou 111 River. The $40 \mathrm{~m}$ deep lake formed by this landslide dam persisted for 13 years and 8 months, but 112 disappeared in about 15 minutes when the dam failed on July 27, 2011 (James and de Graffe, 113 2012).

114 De Graff et al. (2012) examined the spatial distribution of factors leading to landslides in 115 Dominica, and produced a susceptibility map. On this map, most of Dominica is in the moderate 
116 to high risk of landslide activity. Some small regions of extreme landslide risk were identified in

117 the Layou, Belfast, and Geneva river basins.

\section{Analysis of Radar Observations of TS Erika}

119 The French Meteorological Agency MeteoFrance operates two S-band weather radars on 120 the islands adjacent to Dominica in the Lesser Antilles. The S-band radar on Martinique, the 121 island immediately south of Dominica, has a 1.3 degree beam width, but unfortunately 122 experiences significant beam blockage in the direction of Dominica caused by topography on

123 Martinique. The S-band weather radar on Guadeloupe, which is north of Dominica at a range of 12475 to $120 \mathrm{~km}$, has a less desirable 2.1 degree beam width, but has an unobstructed view in the 125 direction of Dominica. Data from this radar were used to estimate storm total rainfall.

126 According to the metadata included in the headers of the data files, the radar on 127 Guadeloupe is sited at $16^{\circ} 18^{\prime} 58^{\prime \prime} \mathrm{N}, 61^{\circ} 20^{\prime} 45^{\prime \prime} \mathrm{W}$, at an elevation of $30 \mathrm{~m}$, on a $13 \mathrm{~m}$ tall 128 pedestal. Its relatively large 2.1 degree beam width makes it more susceptible to range and 129 beam-filling dependent errors (Sharif et al., 2004). When using weather radar for precipitation 130 estimation, it is important to use data from the lowest elevation angle not contaminated by 131 ground clutter (Battan, 1973). A beam propagation analysis was performed using the 132 methodology of Sharif et al. (2004) to identify the lowest unobstructed beam elevation angle.

133 The atmospheric sounding recorded by a weather balloon launched from Guadeloupe at 12:00

134 UTC on 27 August, 2015, was used in this beam propagation analysis, and is listed in Table 1.

135 The relative humidity values in this sounding indicate that the atmosphere was very nearly 136 saturated below $605 \mathrm{mb}$ or $4323 \mathrm{~m}$ elevation. At the time of this sounding, the precipitable water 137 amount was $67 \mathrm{~mm}$. This is a high amount of precipitable water for the tropics (Vatow et al., 
138 2015, Figure 6), and indicates that the circulation associated with TS Erika encountered abundant

139 moisture in the vicinity of Dominica.

140 Figure 2 shows calculated radar beam paths for different antenna elevation angles

141 (degrees). Notice that the 0-degree beam path is completely intercepted by the island of

142 Dominica. The 1.6-degree elevation angle is the lowest one that clears most of the topography

143 given the 2.1-degree beam width. Therefore, data from the 1.6 degree elevation angle were used

144 in this analysis to estimate rainfall rates.

146 The radar reflectivity data were converted into a range versus time plot to identify any 147 data irregularities. On this plot instances of ground clutter appeared as intermittent strong 148 returns at a fixed range against a moving background of returns from rainfall. This plot showed 149 three mountain peaks that were occasional sources of ground clutter during periods of anomalous 150 beam propagation (Battan, 1973). These included the most northward volcano and the two 151 tallest volcanoes on the island. A total of 24 radar pixels where ground clutter occurred in the 1.6

152 degree elevation angle data were used to create a clutter mask, where radar data were omitted.

153 Radar reflectivity values in these relatively small masked areas were interpolated using inverse 154 distance-squared interpolation from the four nearest radar pixels.

155 Radar-Rainfall Mean Field Bias Adjustment Using Hourly Rain Gauge Data

156 The radar reflectivity factor $Z$ is proportional to the sixth moment of the raindrop size

157 distribution (Battan, 1973). For this reason, $Z$ can take on a very wide range of values and is

158 commonly expressed using decibel units (dBZ). The units of $Z$ are $\mathrm{mm}^{6} \mathrm{~m}^{-3}$ and the conversion

159 between $Z$ and $\mathrm{dB} Z$ is: $\mathrm{dB} Z=10 \log _{10} Z$.

160 The form of the widely used radar reflectivity factor $Z$ vs. rainfall rate $R$ relation is: 


$$
Z=\alpha R^{\beta}
$$

161 Where:

$162 Z=\quad$ radar reflectivity factor $\left(\mathrm{mm}^{6} \mathrm{~m}^{-3}\right)$,

$163 R=\quad$ rainfall rate $\left(\mathrm{mm} \mathrm{h}^{-1}\right)$,

$164 \alpha=\quad$ empirical coefficient, and

$165 \beta=\quad$ empirical exponent.

166 Published $Z-R$ relations cover many different situations, but in reality the relationship

167 between radar reflectivity factor and the rainfall rate is non-unique and varies in both space and

168 time. The "standard" tropical $Z-R$ relation uses parameters $\alpha=250$ and $\beta=1.2$, with the 169 reflectivity in decibel units (dBZ) limited to $50 \mathrm{dBZ}$ (Rosenfeld et al., 1993). This limit requires

170 that measured reflectivities greater than $50 \mathrm{dBZ}$ are set to $50 \mathrm{dBZ}$, and is sometimes called a 171 "hail cap" as it serves to eliminate hail contamination from the signal. The effect is to limit the 172 maximum rainfall rate to $147 \mathrm{~mm} \mathrm{~h}^{-1}$ using the standard tropical $Z-R$ relation parameters given in 173 this paragraph.

174 This standard tropical $Z-R$ relation was applied using the Guadeloupe radar data set and 175 compared hourly against data from 8 tipping-bucket rain gauges operated by the Dominican 176 Meteorological Service for the duration of TS Erika. These eight tipping bucket rain gauges 177 were described by Smith et al. (2012). Rainfall estimated using the standard tropical $Z-R$ relation 178 was only $57 \%$ of the rain gauge accumulations on average, as determined by linear regression of 179 hourly radar versus rain gauge rainfall.

180 Linear regression of radar versus gauge allowed detection of outliers in the rain gauge 181 data set. Four hours of data from the Springfield gauge (Smith et al., 2012) were eliminated 182 from the regression as outliers because this gauge greatly under-measured the rainfall values for 
183 those four hours compared to all other gauges in the network and the radar. The reason for this

184 significant gauge under-measurement is unknown. A partially- or completely-plugged rain gauge

185 funnel is a common cause of under-measured rainfall.

186 One consideration when using rain gauges to calibrate radar observations for a particular

187 storm is the proximity of the rain gauges to the area of interest. In other words, how

188 representative is the calculated radar-gauge bias at points that are different distances from the

189 gauge? Using 5-years of warm season radar observations and rain gauge data from the

190 Mississippi river basin, Rogalus and Ogden (2013) found that the correlation coefficient

191 between single-polarization radar-rainfall biases computed using at rain gauges separated by less

192 than $25 \mathrm{~km}$ was $r^{2}=0.42$ for storms with duration 4 hours or longer. The relatively small size of

193 the island of Dominica and relatively long duration of the storm both help reduce spatial

194 variability in radar-gauge bias. However, because of the orographic enhancement of the storm,

195 the possibility that there was significant spatial variability of the radar-gauge bias cannot be 196 ruled out.

197 Following quality control of the rain gauge data, the coefficient $\alpha$ in the Z-R relation 198 (Equation 1) was adjusted to force the slope of the radar vs. gauge regression line to equal 1.0. 199 This procedure is known as mean field bias adjustment (Steiner et al., 1999). After removing the 200 outliers from the Springfield gauge, the value of the coefficient $\alpha$ in Equation 1 was 201 systematically varied until the slope of the regression line between hourly radar and rain gauge 202 rainfall became equal to 1.0. The resulting value was $\alpha=132$. This decrease in $\alpha$ had the effect 203 of increasing the radar-estimated rain rates. The $50 \mathrm{dBZ}$ hail cap with this $\alpha$ value with $\beta=1.2$ 204 represents a rainfall rate of $251 \mathrm{~mm} \mathrm{~h}^{-1}$. The calibrated hourly radar versus rain gauge rainfall 
205

206

207

208

209

210

211

212

213

214

215

216

217

218

219

220

221

222

223

224

225

226

accumuluations are plotted in Figure 3, and the four culled outliers from the Springfield rain gauge are denoted, and were not used in the regression.

Comparing the storm total rainfall for the calibrated relation $Z=132 R^{1.2}$ with and without the $50 \mathrm{dBZ}$ hail cap allowed identification of the effect of the hail cap. The largest difference at any point across the island was a 4 percent reduction in storm-total rainfall with the hail cap in effect. It is safe to conclude that the application of the $50 \mathrm{dBZ}$ hail cap had little impact on the radar-rainfall estimation results.

The results shown in Figure 3 indicate that the hourly bias-adjusted radar-rainfall estimates are reasonably accurate $\left(r^{2}=0.86\right)$. This is despite the relatively large 2.1 -degree radar beam width, $75-120 \mathrm{~km}$ range, and the necessity of using a relatively large 1.6-degree elevation angle to avoid topographic contamination of the radar signal.

$<$ Figure 3 $>$

\section{Island-Wide Isohyetal Map for TS Erika}

Bias-adjusted and clutter-filtered radar rainfall rates were integrated over the island for the period from 00:00 UTC to 23:59 on August 27, 2015, to produce the rainfall storm-total isohyetal $50 \mathrm{~mm}$ contour interval map shown in Figure 4. This figure includes shaded topography with a contour interval of $300 \mathrm{~m}$ to illustrate how the topography of the island clearly played a role in triggering precipitation. Precipitation maxima occur on the eastern slopes of several prominences.

The temporal distribution of island-wide rainfall from TS Erika is shown in Figure 5. Hourly average island-wide rainfall rates were integrated from the Guadeloupe radar data, with 
227 rainfall rates calculated using $Z=132 R^{1.2}$. For three consecutive hours the average rainfall rate 228 over the entire island of Dominica exceeded $80 \mathrm{~mm} \mathrm{~h}^{-1}$.

Also shown on Figure 5 is the cumulative island-wide rainfall, which totaled $508 \mathrm{~mm}$

230 over the duration of TS Erika, with $400 \mathrm{~mm}$ of this rain falling between 08:00 and 12:00 UTC.

231 This estimate was produced from bias-adjusted and clutter-filtered radar rainfall estimates.

\section{Indirect Peak Discharge Measurements}

A total of 16 rivers were selected for indirect peak discharge (IPD) measurements with the assistance of the Hydrometeorology Working Group of the Government of Dominica. Those rivers are shown on Figure 6 with the watershed area above each measurement point. The actual location of the survey varied in terms of distance from the coast because the suitability of a particular river reach for IPD measurements depends upon local conditions such as access, identifiable high-water marks, post-event changes, channel morphology, and the presence of large woody or other debris. Each river in Dominica ends in an alluvial fan at the coast. Most surveyed cross sections were performed upstream of the head of the fan, in a confined cross 242 section.

IPD measurements were made using the U.S. Geological Survey (USGS) Slope-Area

245 Method (Dalrymple and Benson, 1968; USGS, 1994). The essence of the method is that

246 Manning's equation is used based on several surveyed channel cross-sections which provide the

247 cross-sectional area and slope of the water surface. Values for the Manning roughness

248 coefficient were identified based on personal experience using visual clues from the USGS report

249 entitled "Roughness Characteristics of Natural Channels", which is available online 
250 (http://pubs.usgs.gov/wsp/wsp_1849/html/pdf.html ). The USGS slope-area program "SAC"

251 was run on the surveyed data sets. This program requires identification of Manning $n$ values for

252 the main channel, as well as the left- and right-overbank areas.

253 The quality of the IPD measurement is noted in each instance. Factors considered 254 include: agreement of the left- and right-hand high water marks, obvious indications of large 255 changes in the cross-section during the event, uncertainty regarding roughness coefficient values, 256 and the amount of overbank flow. These quality indicators were used to subjectively indicate an 257 uncertainty bound on the indirect peak flow measurement of either $\pm 25 \%$, or $\pm 50 \%$ as per the 258 recommendation of the U.S. Geological Survey (USGS 1994).

259 The global envelope curve for maximum observed flood peaks (ICOLD, 2002) in 260 watersheds with area less than $300 \mathrm{~km}^{2}$ published by the International Congress on Large Dams 261 is given by Equation 2. This envelope represents the largest flood peaks $Q$ for natural floods not 262 due to dam failure observed for a watershed of area $A$, anywhere on the planet.

$$
\frac{Q}{Q_{1}}=\left(\frac{A}{A_{1}}\right)^{1-\frac{E}{10}}
$$

263 with:

$264 A=$ watershed area $\left[\mathrm{km}^{2}\right]$

$265 Q_{1}=10000\left[\mathrm{~m}^{3} \mathrm{~s}^{-1}\right]$

$266 A_{1}=300\left[\mathrm{~km}^{2}\right]$

$267 \quad E=2.1[-]$

\section{Indirect Peak Discharge Results}

The results of IPD measurements are listed in Table 2. This table also lists the subjective 
271 measurements against the global maximum envelope curve (ICOLD, 2002; Rodier and Roche,

272 1984) for instantaneous peak flood flows $\left(\mathrm{m}^{3} \mathrm{~s}^{-1}\right)$, as a function of watershed area $\left(\mathrm{km}^{2}\right)$. This

273 comparison provides an indication of the appropriateness of the magnitude of the IPD

274 measurements. Values of peak flow in excess of the envelope curve are either erroneous, or the

275 result of failure of a landslide dam above the measurement site. The IPD measurement is also

276 listed as a ratio of the envelope value. Ratios in excess of 1.0 are most likely affected by

277 landslide dam failure, or possibly by uncertainties in the IPD measurement.

278 Rivers in Dominica are among the steepest in the world. The quality of the high water

279 marks in the surveyed reaches varied considerably. The Belle Fille, Castle Bruce, Melville Hall,

280 and Rosalie Rivers all had well defined high water marks, flows confined to one main channel,

281 and a reasonably straight channel reach. For these reasons, indirect peak flow measurements in

282 those channels are given $25 \%$ uncertainty. In contrast, large differences in left and right bank

283 high water marks are possible in steep channels with supercritical flows, particularly with the

284 large sediment sizes and braided channels seen in Dominica. The high water elevations

285 identified on the left and right banks of the Hampstead River below Chaudier's Pool, Malabuka

286 River, and Rosalie River each showed about $2.0 \mathrm{~m}$ difference. The uncertainty of the peak flow

287 measurement in those rivers is given as $50 \%$.

288 IPD measurements from this study are plotted in Figure 7 as blue triangles, together with

289 the flood peaks reported in ICOLD (2002) shown as filled black circles. The IPDs from

290 Dominica during TS Erika above the envelope curve shown in Figure 7 are almost certainly

291 affected by landslide dam failure. Peak discharges below the envelope curve range from $23 \%$ to

$29294 \%$ of the envelope value for each given watershed area, with a mean value of $59 \%$. It is not

293 possible to assign a probability of exceedance to this percentage of the envelope curve value, 
294 because it depends on a host of factors that are not well understood such as climate and runoff 295 generation mechanism, as well as the period of record (Castellarin et al., 2005). It is safe to say 296 that $23 \%$ to $94 \%$ of the envelope peak discharge is an extreme event, as demonstrated by the 297 extent of the destruction produced by the flooding that resulted from TS Erika.

298

300

301

302

303

304

305

306

307

308

309

310

311

312

313

314

315

\section{$<$ Figure 7 $>$}

The results in Table 2 show that the Malabuka watershed $\left(1.63 \mathrm{~km}^{2}\right)$ was most severely affected by landslide dam failure. The measured IPD was more than 7 times the maximum envelope curve peak discharge. In the Dubuc $\left(0.9 \mathrm{~km}^{2}\right)$ and Geneva $\left(7.26 \mathrm{~km}^{2}\right)$ rivers the measured IPDs were over 2 times the envelope maximum peak discharge. In the case of the previously mentioned Belfast River, the IPD was $152 \%$ of the envelope curve value. It is noteworthy that portions of the Belfast and Geneva river basins were identified by De Graff et al. (2012) as at extreme risk of landslides. In both the Geneva and Dubuc rivers, landslide dams were noted as having had occurred in our interviews with local residents during our field survey.

\section{Hydrologic Modeling for Landslide Dam Failure Identification}

While the flood peaks shown in Figure 7 above the ICOLD envelope curve were almost certainly affected by landslide dam failure, it is possible that some of the flood peaks below the ICOLD envelope were significantly increased by landslide dam failure. This happens when naturally occurring landslides block the channel, fill with water, then fail. This failure releases a torrent of water that represents a larger flood peak than what would have occurred due solely to rainfall-runoff processes.

On 27 August, 2015, many landslides occurred in Dominica. We observed many small and a few large landslides during post-event field investigations. This provides strong evidence 
316 that enough rain fell to fill most of the pore space in tropical saprolitic soils, because soil

317 saturation is associated with the occurrence of landslides (Rouse et al. 1986). The Gridded

318 Surface/Subsurface Hydrological Analysis (GSSHA) model was used to detect possible landslide

319 affected flood peaks below the ICOLD envelope. GSSHA is a process-based numerical

320 hydrological model (Downer and Ogden, 2006) developed and maintained by the US Army

321 Corps of Engineers for engineering hydrology studies and hydraulic design (Fatichi et al., 2016).

322 GSSHA can simulate infiltration-excess runoff using an infiltration equation. It can also

323 simulate saturation excess runoff with the addition of groundwater flow solution that is coupled

324 to the surface using Richards' equation. Simulations using Richards' equation are much more

325 computationally demanding. Using hillslope scale rainfall-runoff data from the Panola

326 Mountain, Georgia (USA) research site, Ameli et al. (2015) compared rainfall and runoff data

327 with the performance of models that simulated either rapid subsurface stormflow or surface

328 runoff generation mechanisms. They found that both models were able to simulate observations

329 using realistic parameter values. This finding supports the notion that in general, it is possible

330 with the GSSHA model to simulate a range of soil or land-use dependent hydrologic behaviors

331 assuming infiltration-excess runoff generation. GSSHA was previously shown to be quite

332 sensitive to the soil hydraulic conductivity, overland and channel roughness coefficients,

333 retention storage and plant interception of rainfall (Senarath et al., 2000). The sensitivity of

334 GSSHA to initial soil moisture values can be mitigated by performing continuous simulations, as

335 the influence of the initial guess diminishes after the first significant rainfall event (Senarath et

336 al. 2000), or by using measured soil moisture values (Hendrickx et al. 2015). However, in the

337 case of extreme rainfall with more than a few $\mathrm{cm}$ of rain, the effect of the initial soil moisture 
338 state is negligibly important because as cumulative infiltration increases, the infiltration rate

339 rapidly goes towards the limiting value of infiltration, $K_{\text {sat }}$.

340 Interception of rainfall by vegetation was neglected. Numerous studies have found that

341 tropical forests intercept about 17 percent of rainfall (Niedzialek and Ogden, 2012) regardless of

342 total rainfall. This is possible because rainfall evaporates off the leaves before falling to the

343 ground as throughfall. However, in truly extreme events such as TS Erika, it was highly unlikely

344 that 17 percent of rainfall evaporated during the event because the lower troposphere was very

345 nearly saturated with water vapor as indicated by the sounding in Table 1. Interception was most

346 likely greatly reduced during TS Erika.

347 Infiltration was simulated using the Green \& Ampt with Redistribution method (Ogden

348 and Saghafian, 1997), assuming that the soil matrix saturated hydraulic conductivity $K_{\mathrm{s}}=2.0 \mathrm{~cm}$

$349 \mathrm{~h}^{-1}$, (Hassler et al., 2011), the Green and Ampt soil capillary head parameter $H_{\mathrm{c}}=10 \mathrm{~cm}$, pore

350 distribution index $\lambda=0.234$, residual saturation $\theta_{r}=0.015$, field capacity $\theta_{f}=0.30$, wilting point

351 water content $\theta_{\mathrm{w}}=0.15$, and effective porosity $\theta_{\mathrm{e}}=0.50$. Because over $200 \mathrm{~mm}$ of rain had fallen

352 in the two weeks preceding Erika, the initial soil moisture content was assumed everywhere

$353 \theta_{\mathrm{i}}=0.45$, representing $90 \%$ saturation.

354 Land use effects were not considered because most of the watersheds simulated are

355 predominantly a mixture of old and secondary forest that has regrown since Hurricane David in

356 1979. There is low intensity suburban development upstream from Roseau. This includes a few

357 traditional housing developments in flatter areas near streams, but otherwise development

358 consists of houses constructed at uneven spacings adjacent to sparse roads. There are very few

359 roads inland. Ogden et al. (2011) found that the effect of imperviousness on flood peaks 
diminishes with increasing rainfall amounts as soil infiltration capacity becomes overwhelmed,

361 masking the effects of imperviousness.

362 The Watershed Modeling System interface was used to set up the GSSHA models using a

$36330 \mathrm{~m}$ digital elevation model (DEM) using the TauDEM software (Tarboton, 2001). Channels

364 were identified using a channel initiation threshold of $0.1 \mathrm{~km}^{2}$ in watersheds greater than $3 \mathrm{~km}^{2}$

365 in area and $0.04 \mathrm{~km}^{2}$ in smaller watersheds. The identified channel network was trimmed to

366 eliminate short channels and edited to eliminate reaches with adverse slope, which can arise

367 because of DEM errors. The channels were assumed trapezoidal in section with side slope of 1.0

$368 \mathrm{H}: \mathrm{V}$ and channel bottom widths $b(\mathrm{~m})$ assigned based on the contributing area $A\left(\mathrm{~km}^{2}\right)$ using the

369 following equation that fit the survey cross-section data:

$$
b=16.7 \mathrm{~A}^{0.3}(\mathrm{~m})
$$

370 Model Results

GSSHA was run on the 16 watersheds with IPD measurements shown in Figure 7, using

372 parameters previously described and the mean-field bias-adjusted radar-rainfall estimates as

373 forcing. If the model did not produce a peak discharge larger than the indirect measurement,

374 then it is likely that the peak was influenced by landslide dam failure. Those simulation results 375 are shown in Table 3.

376 Landslide dam failure most likely affected peak flows if the relative difference between

377 the GSSHA simulated peak discharge and indirect peak measurement was more negative than

$378-25$ percent in Table 3. Using this criterion, six of the 16 watersheds simulated were identified as

379 obviously landslide affected. These watersheds include all portions of Dominica that were

380 identified as having high to extreme landslide risk (De Graff et al., 2012). 

greater than the indirect measurement. The average difference of the simulations tabulated in

383 Table 3 that were not landslide affected is $27 \%$, while the average absolute difference is $32 \%$.

384 These differences are less than the $25 \%$ nominal IPD measure uncertainty in four of the 11

385 watersheds. These results indicate that the GSSHA model has some skill in predicting peak

386 discharges using soil parameters from the literature, radar-rainfall estimates, and 387 geomorphologically-estimated channel cross-section properties.

GSSHA was used to simulate 24 additional watersheds shown in Figure 8 to estimate

389 peak discharges in those watersheds due to TS Erika. The same watershed parameters were used

390 as in the simulations of the 16 watersheds with IPD measurements. The results of those

391 simulations are given in Table 4.

392

\section{$<$ Figure 8 $>$}

The results in Table 4 show that simulated runoff efficiencies varied from a low of 40 394 percent in the case of the Gillon watershed, to a high of 66 percent in the Macoucherie river watershed. The GSSHA simulated peak discharge values from the 24 watersheds listed in Table 4 plus the 16 watersheds listed in Table 3 are plotted vs. drainage area in Figure 9. This figure also includes the ICOLD peak discharge envelope for watersheds less than $300 \mathrm{~km}^{2}$ in area. The best fit line through the simulated flood peaks has a slope of 0.998 on log-log axes with a 399 coefficient of determination $r^{2}=0.93$.

Six of the watersheds in Figure 9 (Macoucherie, Hampstead, Castle Bruce, Rosalie, 401 Malabuka, and Geneva) are also in the set of 16 watersheds where IPD measurements were 402 made. While most of the IPD measurements were made some distance from the coast, the 403 simulation results reported in Table 3 represent hydrographs predicted at a point very near the 
404 coast, and represent a significantly larger catchment. For example, the IPD measurement on the

405 Castle Bruce River was made at a drainage area of $13.46 \mathrm{~km}^{2}$ (Table 2) while the simulation on 406 the same river reported in Table 3 was performed at a watershed area of $44.07 \mathrm{~km}^{2}$.

407

408

409

410

411

412

414

415

\section{$<$ Figure 9 $>$}

Scaling of flood peaks is an active area of research. The slope of the regression equation through the peak discharges in Figure 9 is very nearly 1.0, which indicates that the peak discharges increased linearly with drainage area for this event. In this case the leading coefficient of the regression equation given in Figure 9 is analogous to a rainfall rate. That rainfall rate is $134 \mathrm{~mm} \mathrm{~h}^{-1}$, which is equivalent to a unit discharge of $37.2 \mathrm{~m}^{3} \mathrm{~s}^{-1} \mathrm{~km}^{-2}$. The results in Figure 9 provide an indication that the GSSHA simulations of ungauged basins with soil hydraulic parameters previously given provide plausible peak discharges relative to the ICOLD maximum discharge envelope. This linear response is likely influenced by the relatively small sizes of the watersheds and the relatively uniform distribution of rainfall across the island (Figure 4). Furthermore, the smaller watersheds simulated tended to be nearer the coast where the storm total rainfall was less than in the interior of the island.

\section{Analysis of Peak Runoff Extremity}

Truly extreme runoff events can approach a condition where the peak rate of flow leaving the watershed is very nearly the rate of water entering the watershed as rainfall less some constant loss rate. This is one physical justification behind the concept of the peak runoff rate envelope curve. In smaller catchments, the envelope limit is reached when the atmosphere provides the maximum possible rainfall rate for a long enough time that the entire watershed area contributes to runoff. The $300 \mathrm{~km}^{2}$ break in the ICOLD envelope curve might be hypothesized to represent the approximate upper limit of the areal extent at which atmosphere can produce 
427 torrential rainfall. Above this $300 \mathrm{~km}^{2}$ limit, the likelihood that torrential rainfall covers the 428 watershed becomes diminishingly small.

429 Three dimensionless parameters were used to evaluate the extreme nature of the runoff 430 generation process. The first was the runoff efficiency, $\rho$, which is the ratio of the storm total 431 depth of runoff $R_{t o t}[\mathrm{~mm}]$ to the integrated total depth of rainfall over the area of the watershed, $432 I_{t o t}[\mathrm{~mm}]:$

$$
\rho=\frac{R_{\text {tot }}}{I_{\text {tot }}},
$$

433

434 The second parameter was the peak dimensionless runoff rate, $r_{p}{ }^{*}$, which represents the peak rate 435 of runoff normalized by the peak rate of rainfall minus the saturated hydraulic conductivity of the 436 soil $K_{\text {sat. }}$ The radar-rainfall estimated watershed-average peak rainfall rate is $i_{p}\left[\mathrm{~mm} \mathrm{~h}^{-1}\right]$ and the 437 peak runoff rate from GSSHA simulations is $r_{p}\left[\mathrm{~mm} \mathrm{~h}^{-1}\right]$, and therefore the dimensionless peak 438 runoff rate $r_{p}{ }^{*}$ was calculated using:

$$
r_{p}^{*}=\frac{r_{p}}{i_{p}-K_{s a t}}
$$

439 The third parameter is the ratio of the peak discharge $Q_{\mathrm{p}}\left[\mathrm{L}^{3} \mathrm{~T}^{-1}\right]$ to the envelope curve 440 peak runoff ratedischarge $Q_{e n v}\left[\mathrm{~L}^{3} \mathrm{~T}^{-1}\right]$. This parameter indicates the severity of the flooding 441 relative to the ICOLD envelope curve. By Equation 2, $Q_{e n v}$ that is assumed to be solely a 442 function of watershed area $A$. The envelope peak discharge ratio to produce a dimensionless 443 peak discharge $Q_{p}{ }^{*}$ : was calculated using:

$$
Q_{p}^{*}=\frac{Q_{p}}{Q_{e n v}(A)}
$$


446 determine if the modeled peak discharge in any of the watersheds approached equilibrium 447 conditions during TS Erika. The use of modeled hydrograph properties in this graph removes the 448 effects of landslide dam failure. Those watersheds in the upper right-hand portion of the figure 449 were most severely affected with $Q_{p} *>0.8$, which include the Macoucherie, Coulibistrie, and 450 Hampstead rivers. A second group with $0.5<Q_{p} *<0.8$ include the Belfast, Belle Fille, Boeri, 451 Check Hall, Colihaut, Geneva, Melville Hall, Roseau, and Rosalie rivers. Those watersheds with $452 Q_{p}{ }^{*}$ less than 0.5, the Castle Bruce, Dubuc, Malabuka and Pointe Ronde, received less rainfall 453 that the other watersheds and the GSSHA models had peak flow values less than half of the 454 envelope value for equivalent watershed areas.

455 The results in Figure 10 in terms of dimensionless runoff rate divided by peak observed 456 rainfall rate, $r_{p}{ }^{*}$, are not entirely conclusive. While there is a tendency for watersheds with $Q_{p}{ }^{*}$ 457 near 1.0 to have $r_{p}{ }^{*}$ near 1.0 , there were other watersheds with $r_{p}{ }^{*}$ near 1.0 but with $0.3<Q^{*}$ $458<0.8$. This result indicates that for extreme rainfall events in steep tropical watersheds with thin 459 saprolitic soils, the rainfall rate can be a primary determinant of peak discharge, even in cases 460 where $Q^{*}$ is significantly less than 1.0 .

One example of a watershed where equilibrium runoff rates were approached is the 463 Macoucherie river, which was one of the worst affected. The watershed-average rainfall rate and 464 modeled runoff rate $\left(\mathrm{mm} \mathrm{h}^{-1}\right)$ are plotted together in Figure 11, together with the ICOLD 465 envelope and the IPD measurement. Results on Figure 10 indicate that the peak rate of runoff 466 was very nearly the same as the peak rainfall rate. The simulated peak runoff rate from GSSHA 467 was $208 \mathrm{~mm} \mathrm{~h}^{-1}$, while the radar estimated peak watershed-average rainfall rate was $234 \mathrm{~mm} \mathrm{~h}^{-1}$. 
468 The difference is only $26 \mathrm{~mm} \mathrm{~h}^{-1}$, which is only $6 \mathrm{~mm} \mathrm{~h}^{-1}$ more than the simulated $K_{\text {sat }}$ of $20 \mathrm{~mm}$

$469 \mathrm{~h}^{-1}$. This indicates that for the Macoucherie Watershed and others with $Q_{p}{ }^{*}$ values near 1.0 on

470 Figure 10, in the case of this event that was near the envelope curve maximum value, the 471 maximum peak discharge was at least strongly affected or, at most, determined by the maximum 472 observed rainfall rate. 475 storm total rainfall $[\mathrm{mm}]$ in Figure 12 for all watersheds considered. Symbols are used to differentiate between the 16 watersheds where IPD measurements were made and the other 24

477 GSSHA simulation points. The results shown in Figure 12 show an increasing trend in both $r_{p}^{*}$ 478 and $\eta$ with increasing storm total rainfall. These results also suggest that when the storm-total 479 rainfall exceeded $450 \mathrm{~mm}$, the runoff efficiencies reached a maximum value of around 0.6. 480 When the storm total rainfall exceeded $500 \mathrm{~mm}$, the dimensionless peak runoff rates mostly 481 exceeded 0.8. These results indicate that between 450 and $500 \mathrm{~mm}$ of storm total rainfall the 482 available storage in the watershed filled, and the peak runoff rate was closely tied to the peak 483 rainfall rate.

\section{Conclusions}

There are few detailed studies of extreme hydrological events in Caribbean island 487 settings. This paper presents results of a detailed hydrometeorological analysis of Tropical 488 Storm Erika that impacted Dominica on August 27, 2015, causing loss of life and significant 
damages to personal property and public infrastructure, particularly bridges. Bias-adjusted radar

490 rainfall estimates using S-band weather radar observations from Guadeloupe, indicate that this

491 storm produced from between 300 to $750 \mathrm{~mm}$ of rainfall on the island of Dominica, with most of

492 the rain falling during a four hour period. This extremely intense rainfall produced flooding very

493 nearly as severe as naturally possible in some watersheds in the absence of landslide dam failure.

494 This was particularly true in the Macoucherie, Melville Hall, Roseau, and Rosalie rivers.

495 Indirect peak discharge measurements performed in 16 rivers indicated that with some

496 uncertainty, the peak flows resulting from the extreme rainfall associated with TS Erika were

497 near the ICOLD (2002) envelope of maximum flood events recorded anywhere on the planet.

498 In six of the 16 watersheds the failure of landslide dams led to peak flows considerably

499 above the ICOLD (2002) envelope. The IPD measurements also showed that none of the rivers

500 emanating from watersheds greater than $10 \mathrm{~km}^{2}$ area, with the exception of the $13.6 \mathrm{~km}^{2}$ Belfast

501 River, experienced enhanced peak flows due to the catastrophic failure of landslide dams. The

502 effect of landslide dam failure on peak discharge was not a factor in larger watersheds because

503 large landslide dams that can store enough water to alter peak flows in large watersheds are rare.

504 They do happen, as occurred in the Layou river watershed in 1997 (James and Serrant, 1997;

505 James and De Graff 2012), but did not occur during this event.

506 The IPD measurements show that the GSSHA model has some skill in predicting peak

507 flows for TS Erika using the bias-adjusted radar-rainfall inputs from the Guadeloupe weather

508 radar. In addition to the sixteen watersheds with IPD measurements, GSSHA runoff simulations

509 of an additional 24 watersheds produced a broader picture across the entire range of watershed

510 sizes present on Dominica. The simulated peak discharges in the absence of landslide dam 
511 failures were on average, proportional to watershed area. The constant of proportionality was

$512134 \mathrm{~mm} \mathrm{~h}^{-1}$, which represents a unit discharge of $37.22 \mathrm{~m}^{3} \mathrm{~s}^{-1} \mathrm{~km}^{-2}$.

513 The study described in this paper tested the hypothesis that during extreme rainfall events

514 in steep, mountainous, tropical forested watersheds less than about $30 \mathrm{~km}^{2}$ in area, with thin

515 volcanically-derived soils, the peak discharge in streams can in some instances be determined by

516 the rainfall rate less a small constant loss rate. The findings of this study suggest that this did

517 happen in a number of watersheds that approached equilibrium runoff conditions. The results in

518 this study indicate that the available storage was filled after approximately $450 \mathrm{~mm}$ of rainfall

519 over approximately a four hour period, and produced runoff efficiencies in excess of 50 percent,

520 a remarkably high value for the humid tropics. When the storm-total watershed-average rainfall

521 exceeded $500 \mathrm{~mm}$, the dimensionless peak runoff rates exceeded 80 percent of the peak rainfall

522 rate minus a small constant loss rate of $20 \mathrm{~mm} \mathrm{~h}^{-1}$. This information might prove useful for

523 design of resilient infrastructure on tropical volcanic islands in the Caribbean and elsewhere.

\section{Acknowledgments}

525 This study was funded by the Government of Dominica, through the Disaster

526 Vulnerability Reduction Project (DVRP). The two survey crews from the Government of

527 Dominica, from the Ministries of Lands and Surveys and Public Works led by Mr. Ali Cuffy and

528 Mr. Malcolm Bells, respectively, performed the survey work. Michelle Ogden performed

529 admirably as field assistant during our expedition in late October, 2015 and helped in

530 documenting field conditions and editing this paper. Samantha Marquard Ogden assisted with

531 setup of the GSSHA models. Mr. Collin Guiste, and Ms. Andrea Marie and the other staff from

532 the DVRP office in Roseau provided excellent support for field activities. Mr. Stephen Durand 
533 and Mr. Octave Joseph both provided invaluable assistance in the field for their knowledge of the 534 country. The World Bank provided the $10 \mathrm{~m}$ DEM of the island. Mark Smith of the U.S. 535 Geological Survey provided guidance on the application of the USGS Slope Area method. All 536 this support is gratefully acknowledged. The animation of the radar observations from 537 Guadeloupe of TS Erika is available at the following URL: https://www.youtube.com/watch? $538 v=$ WOAOlF30oms 


\section{References}

540 Ameli, A. A., J. R. Craig, and J. J. McDonnell, 2015. Are all runoff processes the same?

$541 \quad$ Numerical experiments comparing a Darcy-Richards solver to an overland flow-based 542 approach for subsurface storm runoff simulation, Water Resour. Res., 51, 10008-10028, 543 doi:10.1002/2015WR017199.

544 Battan, L. J., 1973. Radar observation of the atmosphere.

545 Benson C., E. Clay, F.V. Michael, and A.W. Robertson, 2001. Dominica: natural disasters and 546 economic development in a small island state. Disaster Risk Management Working Paper 547 Series No. 5, Disaster Management Facility, World Bank, Washington, DC

548 Castellarin, A., R. M. Vogel, and N. C. Matalas, 2005. Probabilistic behavior of a regional 549 envelope curve, Water Resour. Res., 41, W06018, doi:10.1029/2004WR003042.

550 Costa J.E., and R.L. Schuster 1988. The formation and failure of natural dams. Geol Soc Am 551 Bull. 100:1054-1068.

552 Dalrymple T. and M.A. Benson, 1968. Measurement of peak discharge by the slope-area 553 method. Techniques in Water-Resources Investigations 03-A2. USGS Numbered Series, 554 Dept. of the Interior. 12 p. Downloaded from: https://pubs.usgs.gov/twri/twri3-

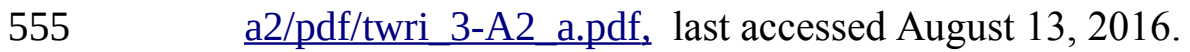

556 De Graff, J. V., H. C. Romesburg, R. Ahmad, J. P. McCalpin, 2012., Producing landslide557 susceptibility maps for regional planning in data-scarce regions, Nat. Hazards, 64;729558 749, DOI 10.1007/s11069-012-0267-5.

559 
Downer, C. W., and F. L. Ogden, 2004. GSSHA: A model for simulating diverse streamflow 561 generating processes, J. Hydrol. Engrg., 9(3):161-174.

562 Downer, C. W. and F. L. Ogden, 2006. Gridded Surface Subsurface Hydrologic Analysis 563 (GSSHA) User's Manual, Version 1.43 for Watershed Modeling System 6.1, System Wide Water Resources Program, Coastal and Hydraulics Laboratory, U.S. Army Corps of Engineers, Engineer Research and Development Center, ERDC/CHL SR-06-1, 207 pp. Available on-line at: $\underline{\text { http://gsshawiki.com/ }}$

Fatichi, S., E. Vivoni, F. L. Ogden, et al., 2016., An overview of current applications, challenges, and future trends in process-based models in hydrology, J. Hydrol. 537, pp. 45-60, DOI:10.1016/j.jhydrol.2016.03.026.

Franklin, J., 2015. After Further Review: Tropical Storm Erika, Blog post https://noaanhc.wordpress.com/2015/09/10/after-further-review-tropical-storm-erika/ posted Sept. 10, 2015, accessed November 14, 2015.

Goldsmith, S. T., A. E. Carey, B. M. Johnson, S. A. Welch, W. B. Lyons, W. H. McDowell, J. S. Pigott, 2010. Stream geochemistry, chemical weathering and CO2 consumption potential of andesitic terrains, Dominica, Lesser Antilles, Geochimica et Cosmochimica Acta, 74(2010)85-103, doi:10.1016/j.gca.2009.10.009.

Hassler, S. K., B. Zimmermann, M. Van Breugel, J. S. Hall, and H. Elsenbeer, 2011. Recovery of saturated hydraulic conductivity under secondary succession on former pasture in the humid tropics, Forest Ecol. Mgmt. 261:1634-1642.

Hendrickx, J.M.H., R. Allen, A.R. Byrd, S. Hong. A. Brower, F.L. Ogden, R. Trezza, N.R. Pradhan, C.W. Robison, D. Toll, T. Umstot, and J.L. Wilson,. 2015, Benchmarking optical/thermal satellite imagery for estimation of evapotranspiration and soil moisture in 

1688.12371 .

585 ICOLD, 2002. Dams and Floods, International Congress On Large Dams (ICOLD) Bull., Paris.

586 James, A., and T. Serrant, 1997. The Carholm-Huxley landslides: an assessment of their impact on the lower Layou River Valley, Dominica, Carib. Geog., 8(2):120-127.

588 James, A., and J.V. De Graff, 2012. The draining of Mattieu landslide-dam lake, Dominica, West 589 Indies. Landlides, 9:529-537, DOI: 10.1007/s10346-012-0333-9.

590 Larsen M.C., 2008. Rainfall-triggered landslides, anthropogenic hazards, and mitigation $591 \quad$ strategies. Adv. Geosci 14:147-153.

592 Lumbroso, D.M., S. Boyce, H. Bast, and N. Walmsley, 2011. The challenges of developing 593 rainfall intensity - duration - frequency curves and national flood hazard maps for the 594 Caribbean, J. Flood Risk Management, 4(1):42-52.

595 Niedzialek, J. M., and F. L. Ogden, 2012. First-order catchment mass balance during the wet 596 season in the Panama Canal Watershed, in press, J. Hydrol. $597 \quad$ doi:10.1016/j.jhydrol.2010.07.044.

598 Ogden, F. L., T. D. Crouch, R. F. Stallard, and J. S. Hall, 2013. Effect of land cover and use on 599 dry season river runoff and peak runoff in the seasonal tropics of central Panama, Water $600 \quad$ Resour. Res. 49(12):8443-8462, doi:10.1002/2013WR013956.

601 Ogden, F. L., and D. R. Dawdy, 2003. Peak Discharge Scaling in a Small Hortonian Watershed, $602 \quad$ J. Hydrol. Engr., 8(2):64-73.

603 Ogden, F. L. and B. Saghafian, 1997. Green and Ampt Infiltration with Redistribution, J. Irrig. 604 Drain. Engrg., 123(5):386-393. 
605 Ogden, F.L., N. Raj Pradhan, C.W. Downer, and J.A. Zahner, 2011. Relative importance of 606 impervious area, drainage density, width function, and subsurface storm drainage on 607 flood runoff from an urbanized catchment. Water Resour. Res., 608 doi:10.1029/2011WR010550.

609 Rodier, J. A., and M. Roche, 1984. World Catalog of Maximum Observed Floods, International 610 Association of Hydrological Sciences, IAHS, Pub. 143.

611 Rogalus, M. R. III, and F. L. Ogden, 2013. Spatial assessment of five years of WSR-88D data over the Mississippi River basin and its estimation bias around rain gauge sites, $J$. Hydrol. Engrg. 18:212-218.

614 Rosenfeld, D., D. Wolff, and D. Atlas, 1993. General probability-matched relations between 615 radar reflectivity and rain rate. J. Appl. Meteor., 32, 50-72.

616 Rouse, W. C., A. J. Reading, and R. P. D. Walsh, 1986. Volcanic soil properties in Dominica, 617 West Indies, Engineering Geol., 23(1986)1-28.

618 Senarath, S. U. S., F. L. Ogden, C. W. Downer, and H. O. Sharif, 2000. On the calibration and 619 verification of distributed, physically-based, continuous, Hortonian hydrologic models, $620 \quad$ Water Resour. Res., 36(6):1495-1510.

621 Sharif, H. O., F. L. Ogden, W. F. Krajewski, and M. Xue, 2004. Statistical analysis of radar622 rainfall error propagation, J. Hydrometeorology, 5(1):199-212.

623 Smith, R. B., J. R. Minder, A. D. Nugent, T. Storelvmo, D. J. Kirshbaum, R. Warren, N. Lareau, 624 P. Palany, A. James, and J. French, 2012. Orographic Precipitation in the Tropics: The 625 Dominica Experiment, Bull. Am. Met. Soc., pp. 1567-1579. 626 http://dx.doi.org/10.1175/BAMS-D-11-00194.1 
627 Steiner, M., J. A. Smith, S. J. Burges, C. V. Alonso and R. W. Darden, 1999. Effect of bias 628 adjustment and rain gauge data quality control on radar rainfall estimation, Water Resour. $629 \quad$ Res., 35(8):2487-2503.

630 Tarboton, D. G., 2001. TauDEM, terrain analysis using digital elevation models, ArcGIS $631 \quad$ Extension, Version 5.

632 USGS, 1994. User's Guide to SAC, a Computer Program for Computing Discharge by Slope633 Area Method., US Geological Survey, Open-File Report 94-360, Janice M. Fulford, 634 Stennis Space Center, Mississippi.

635 Votaw, G., A. Austin-Smith, E. Rodriguez, E. Morales, and F. Castro, Tropical Storm Erika, 636 http://www.srh.noaa.gov/images/sju/climo/Erika.pdf, accessed Dec. 30, 2015.

637 Wohl, E., A. Barros, N. Brunsell, N. A. Chappell, M. Coe, T. Giambelluca, S. Goldsmith, R. 638 Harmon, J. M. H. Hendrickx, J. Juvik, J. McDonnell, F. L. Ogden, 2012. Hydrology of 639 the Humid Tropics, Nature Clim. Change, 2(9)665:662.

640 World Bank, 2004. Dominica: natural disasters and economic development of a small island 641 state. Disaster risk management working papers series No. 2. Disaster Management 642 Facility, Washington, DC.

643 
645 Figure 1. Map of the eastern Caribbean basin showing the location of Dominica and the 646 approximate path of TS Erika at the start of the day shown in the center of the tropical storm 647 symbol, August, 2015. Inset map shows topography of Dominica, contour interval $300 \mathrm{~m}$.

648 Figure 2. Beam path analysis for MeteoFrance radar on Guadeloupe, at an azimuth of 649 approximately 180 -degrees. Shown on the figure is the spine of the island of Dominica.

650 Figure 3. Radar vs. rain gauge comparison with 17 hourly rainfall accumulations at 8 rain 651 gauges during tropical storm Erika, with four hourly values from the Springfield rain gauge 652 removed as outliers as shown. $50 \mathrm{dBZ}$ limit applied.

653 Figure 4. Isohyetal map for TS Erika rainfall (mm) over the island of Dominica, August, 27, 654 2015. Topography denoted with color contours $(300 \mathrm{~m})$. Note two maxima near the highest

655 mountains on the island. Rainfall isohyetal contour interval $50 \mathrm{~mm}$. Rainfall estimated using 656 radar data from S-band radar on Guadeloupe, with calibrated relationship $Z=132 R^{1.2}$ and applied 657 hail cap of $50 \mathrm{dBZ}$.

658 Figure 5. Temporal distribution of radar estimated island-wide average rain rate and cumulative 659 rainfall from TS Erika on 27 August, 2015.

660 Figure 6. Watersheds where IPD measurements were made.

661 Figure 7. Global peak flood discharge envelope curve (solid line) (ICOLD, 2002), and 662 supporting data points (black). The blue triangles represent Dominica watersheds during TS 663 Erika based on IPD measurements from Table 3. 
664 Figure 8. The 24 watersheds simulated with watershed outlet near the coast. The area simulated 665 is listed in Table 4.

666 Figure 9. Simulated peak discharges using GSSHA with soil saturated hydraulic conductivity $667 K_{s}=2.0 \mathrm{~cm} \mathrm{~h}^{-1}$ driven by TS Erika radar-rainfall on 16 watersheds where IPD measurements were 668 made plus the 24 ungauged watersheds shown in Figure 8 (40 total).

669 Figure 10. Simulated peak discharge normalized by the envelope peak discharge $\left(Q^{*}\right)$ versus 670 the peak observed runoff rate normalized by the peak instantaneous excess rainfall rate $\left(r_{p}^{*}\right)$.

671 Both quantities are dimensionless. Watersheds with larger $Q^{*}$ values were worst affected. 672 Effects of landslide dam failure not included.

673 Figure 11. The $12.15 \mathrm{~km}^{2}$ Macoucherie River Watershed neared equilibrium conditions during 674 TS Erika, with the GSSHA simulated runoff rate nearing rainfall rate during the time of peak 675 flow. Error bars on IPD measurement represent \pm 25 percent. Error in time of peak discharge 676 unknown.

677 Figure 12. Dimensionless peak runoff rates $r_{p}{ }^{*}$ and runoff efficiencies $\eta$ for all watersheds 678 considered plotted versus storm-total watershed-average rainfall $(\mathrm{mm})$. 


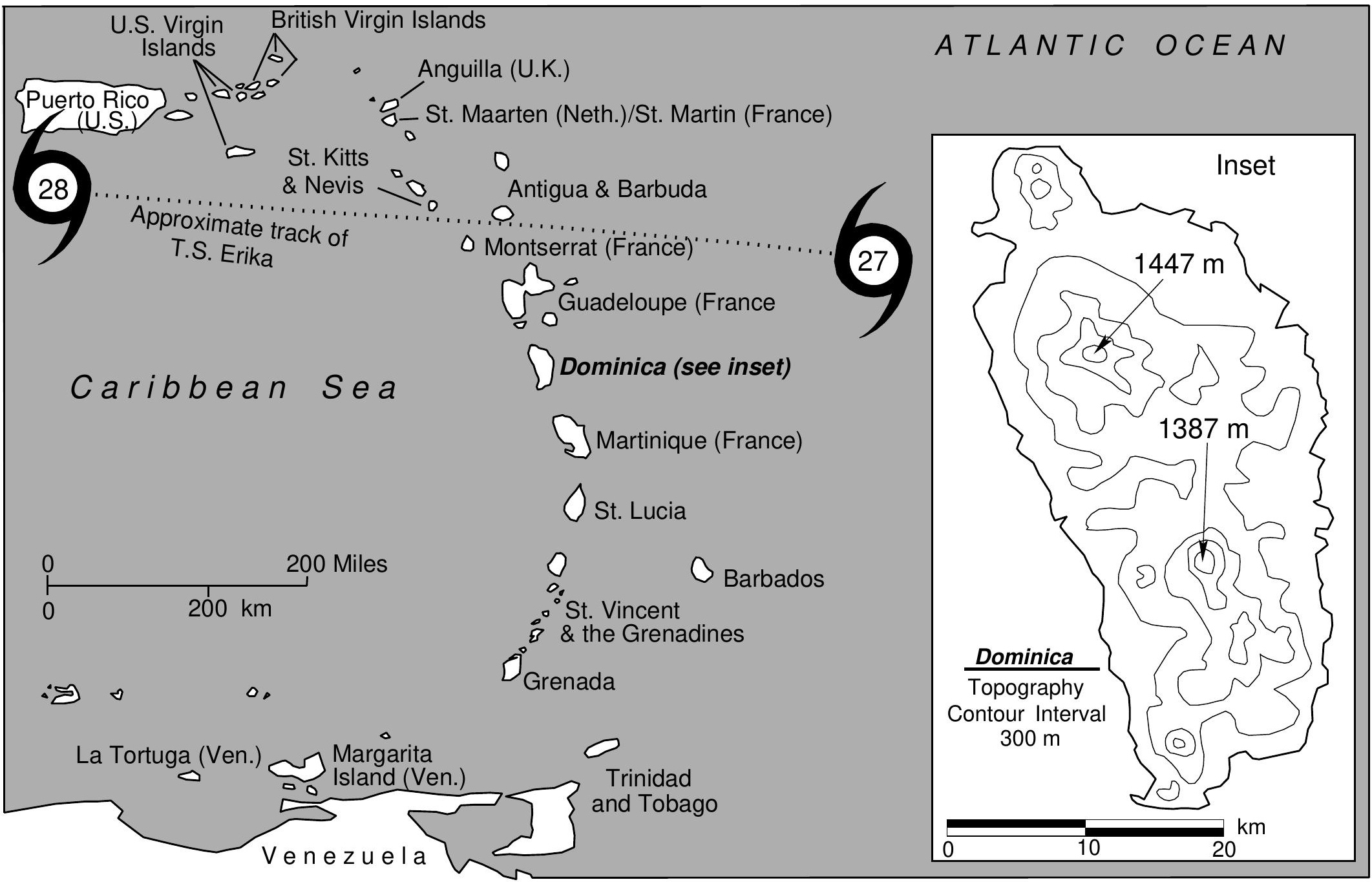




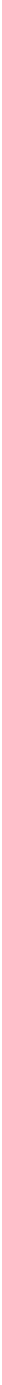




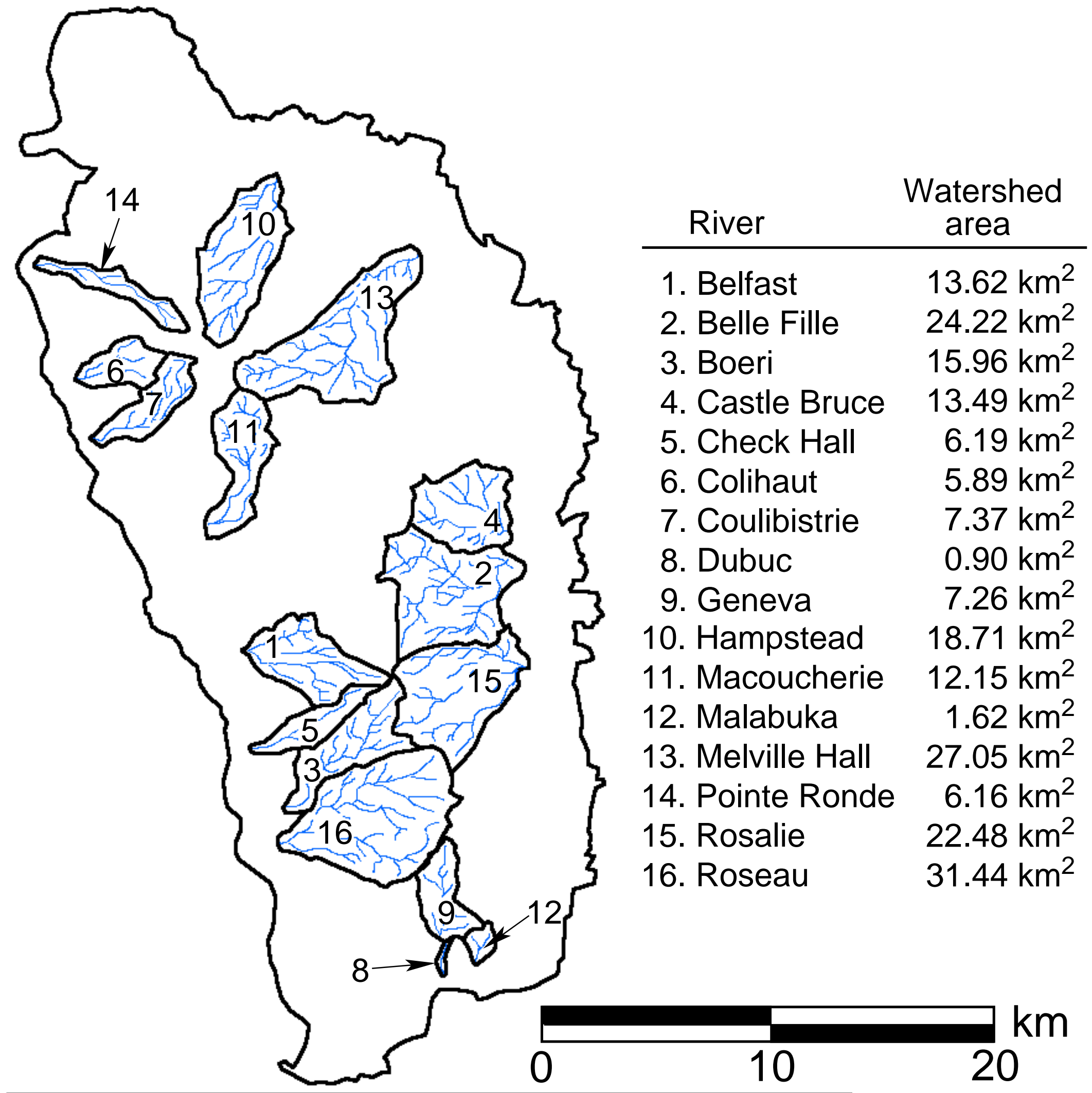




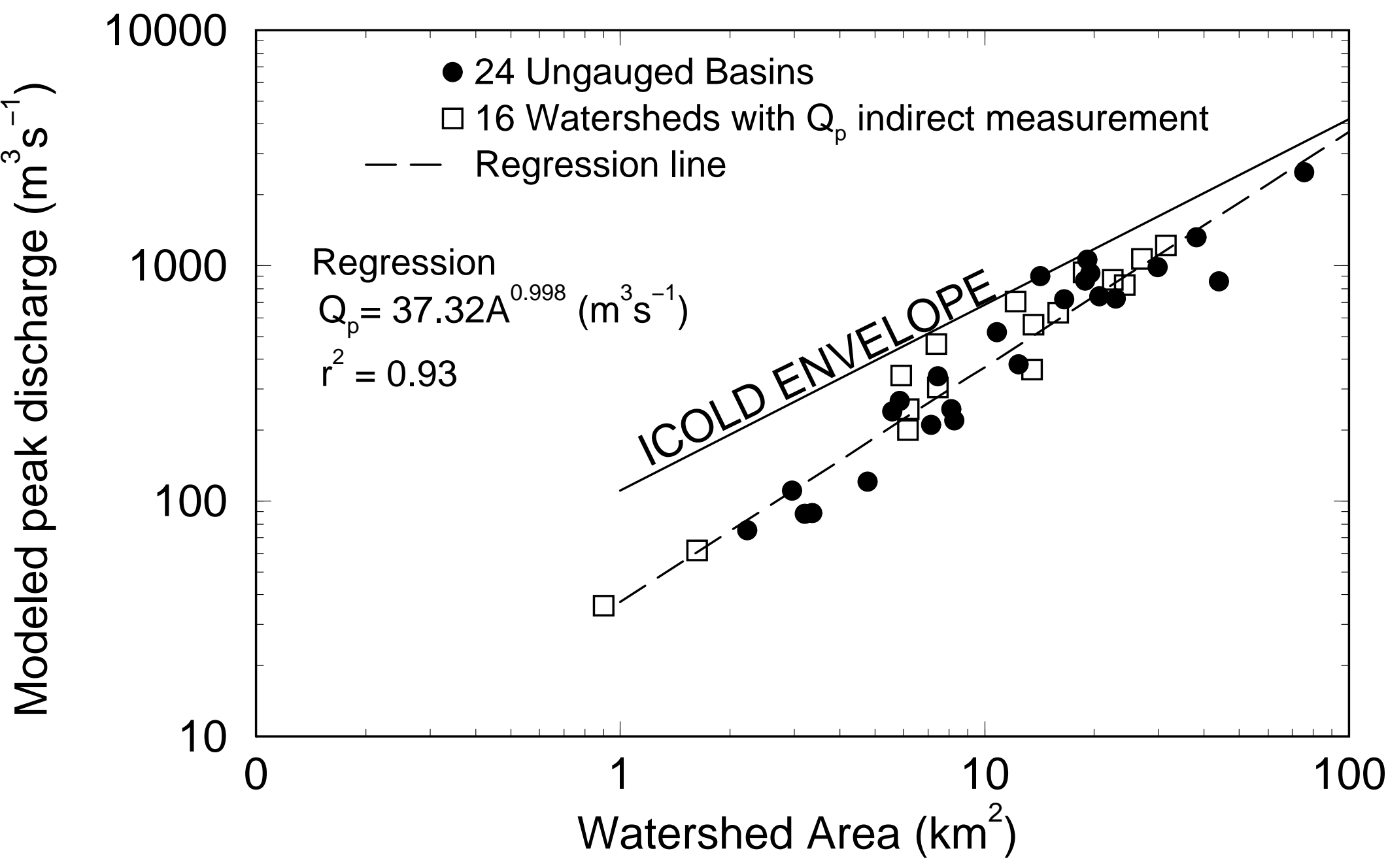




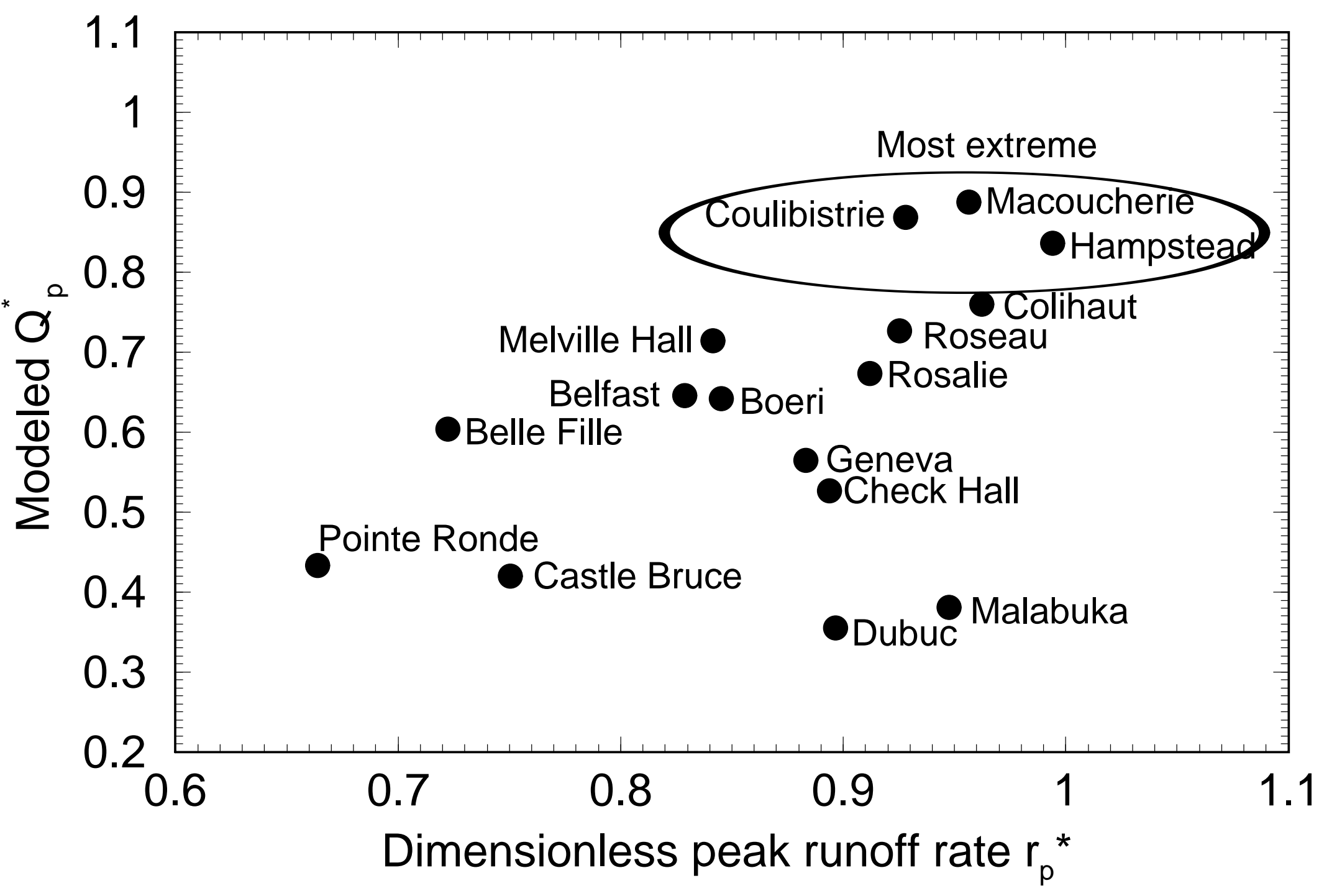




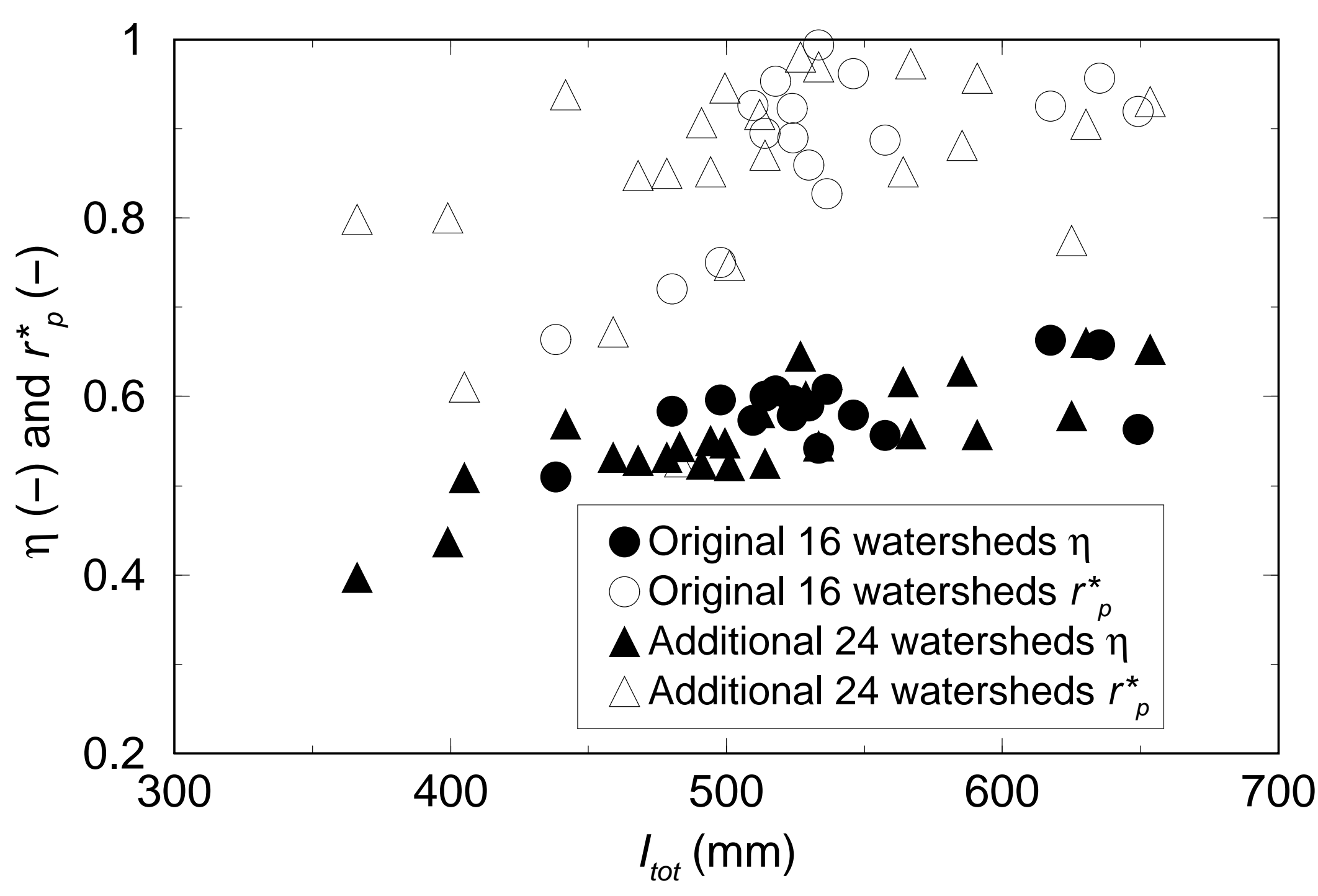

Figure 12 
Table 1. Atmospheric soundings from Station 78897, La Raizet, Guadeloupe, 12:00 UTC 27 August 2015. [Data source: Atmospheric Science Dept., University of Wyoming]

\begin{tabular}{cccc} 
Pressure & Height & Temperature & Relative \\
$(\mathrm{hPa})$ & $(\mathrm{m})$ & $(\mathrm{C})$ & Humidity $(\%)$ \\
\hline 1008 & 11 & 25 & 95 \\
1000 & 73 & 24.8 & 95 \\
929 & 719 & 21.6 & 96 \\
856 & 1428 & 18.3 & 97 \\
817 & 1828 & 16.4 & 97 \\
739 & 2672 & 10.3 & 98 \\
700 & 3123 & 8.6 & 98 \\
660 & 3609 & 7.2 & 99 \\
636 & 3914 & 6.4 & 99 \\
605 & 4323 & 4.2 & 99 \\
546 & 5152 & -0.2 & 83 \\
529 & 5405 & -2.1 & 78 \\
500 & 5850 & -5.7 & 84 \\
464 & 6433 & -9.5 & 92 \\
400 & 7570 & -15.7 & 85
\end{tabular}


Table 2. IPD Measurements and Comparison with Global Envelope Curve with IPD measurement uncertainty.

\begin{tabular}{|c|c|c|c|c|c|c|}
\hline River Name & $\begin{array}{c}\text { Watershed } \\
\text { Area } \\
A \\
\left(\mathrm{~km}^{2}\right)\end{array}$ & $\begin{array}{c}\text { Indirect Peak } \\
\text { Discharge } \\
\text { measurement } \\
Q_{p} \\
\left(\mathrm{~m}^{3} \mathrm{~s}^{-1}\right)\end{array}$ & $\begin{array}{c}\text { Unit } \\
\text { Discharge } \\
Q_{p} / A \\
\left(\mathrm{~m}^{3} \mathrm{~s}^{-1} \mathrm{~km}^{-2}\right)\end{array}$ & $\begin{array}{c}\text { Envelope } \\
\text { Curve } \\
Q_{e n v} \\
\left(\mathrm{~m}^{3} \mathrm{~s}^{-1}\right)\end{array}$ & $\begin{array}{c}\text { Ratio } \\
\mathrm{Q}_{\mathrm{p}} / \mathrm{Q}_{\mathrm{env}} \\
(-)\end{array}$ & $\begin{array}{c}\text { Uncert. } \\
\pm \\
(\%)\end{array}$ \\
\hline Belfast & 13.60 & 1320 & 97 & 868 & 152 & 25 \\
\hline Belle Fille & 24.18 & 656 & 27 & 1368 & 48 & 25 \\
\hline Boeri & 16.19 & 574 & 35 & 996 & 58 & 25 \\
\hline Castle Bruce & 13.46 & 201 & 15 & 861 & 23 & 25 \\
\hline Check Hall & 6.18 & 163 & 26 & 466 & 35 & 25 \\
\hline Colihaut & 5.88 & 218 & 37 & 448 & 49 & 25 \\
\hline Coulibistrie & 7.35 & 855 & 116 & 534 & 160 & 25 \\
\hline Dubuc & 0.90 & 243 & 270 & 102 & 239 & 25 \\
\hline Geneva & 7.26 & 1220 & 168 & 529 & 231 & 25 \\
\hline Hampstead & 18.68 & 677 & 36 & 1115 & 61 & 50 \\
\hline Macoucherie & 12.12 & 742 & 61 & 793 & 94 & 25 \\
\hline Malabuka & 1.63 & 1287 & 790 & 162 & 792 & 50 \\
\hline Melville Hall & 27.01 & 1196 & 44 & 1493 & 80 & 25 \\
\hline Pointe Ronde & 6.16 & 232 & 38 & 464 & 50 & 25 \\
\hline Rosalie & 22.82 & 1233 & 40 & 1307 & 71 & 50 \\
\hline Roseau & 31.38 & 923 & 39 & 1680 & 73 & 25 \\
\hline
\end{tabular}

Notes on Table 2: The global maximum envelope curve peak discharge values as a function of drainage basin area were calculated using Eqn. 3 (ICOLD, 2002) for watersheds less than $300 \mathrm{~km}^{2}$ in area. Differences in high water mark elevations on left and right banks of Hampstead, Malabuka and Rosalie rivers were greater than $2 \mathrm{~m}$. 
Table 3. Peak flow results of GSSHA simulations with soil saturated hydraulic conductivity $K_{\mathrm{s}}=2.0 \mathrm{~cm}$ $\mathrm{h}^{-1}$ on 16 watersheds compared with IPD measurements.

\section{GSSHA}

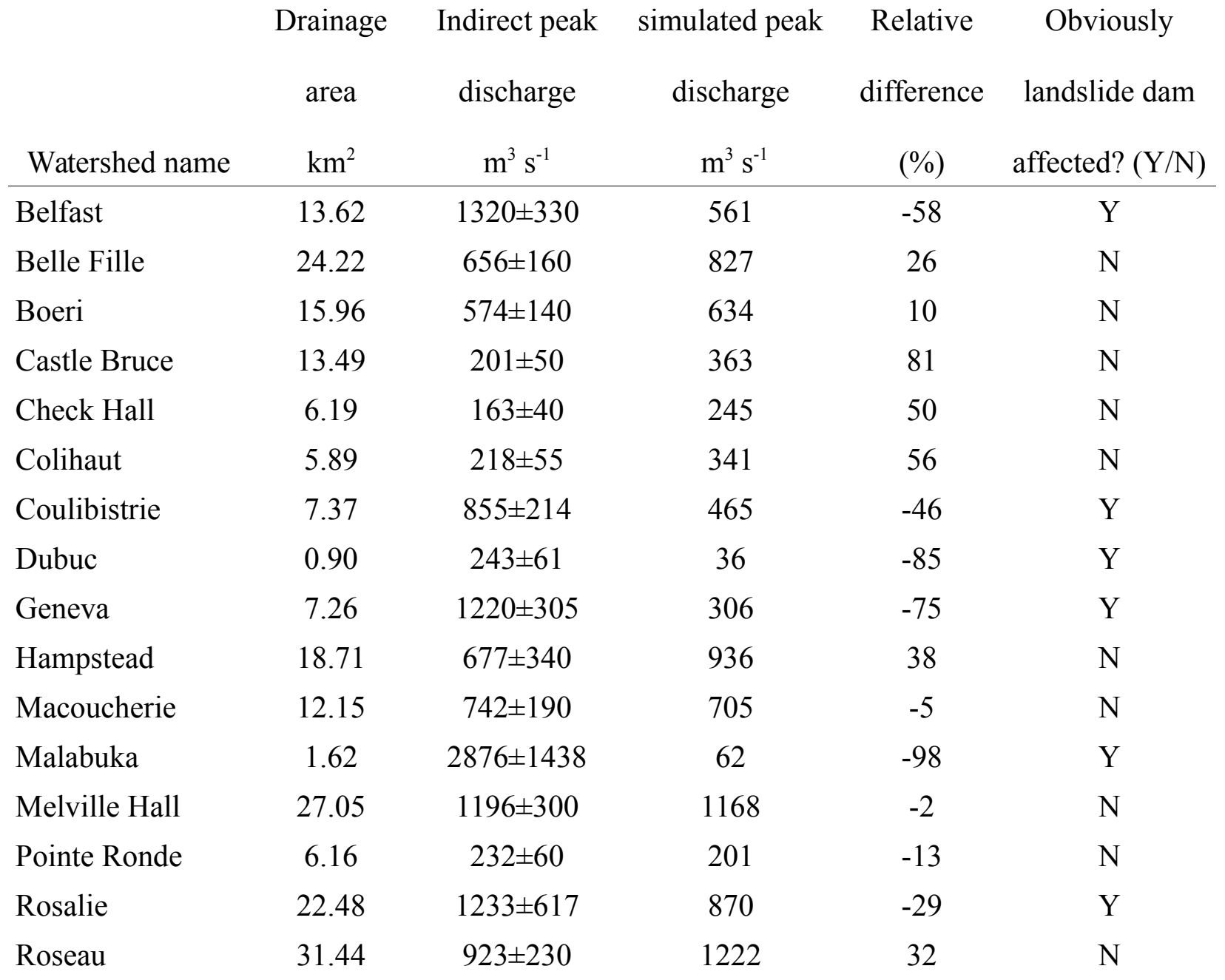


Table 4. Modeled runoff for 24 additional watersheds around Dominica shown in Figure 8.

\begin{tabular}{|c|c|c|c|c|c|c|c|}
\hline & & & & & & $Q_{e n v}$ & \\
\hline & Area & $Q_{\mathrm{p}}$ & Rainfall & Runoff & Runoff & ICOLD & $Q_{p} Q_{e n v^{-1}}$ \\
\hline Watershed name & $\mathrm{km}^{2}$ & $\left(\mathrm{~m}^{3} \mathrm{~s}^{-1}\right)$ & $(\mathrm{mm})$ & $(\mathrm{mm})$ & eff. & $\left(\mathrm{m}^{3} \mathrm{~s}^{-1}\right)$ & $(\%)$ \\
\hline & & & & & $(\%)$ & & \\
\hline Layou & 75.40 & 2495 & 564 & 348 & 62 & 3358 & 74.3 \\
\hline Macoucherie & 19.12 & 1061 & 630 & 416 & 66 & 1136 & 93.4 \\
\hline Batali & 14.20 & 905 & 654 & 427 & 65 & 898 & 100.78 \\
\hline Dublanc & 7.45 & 338 & 514 & 270 & 53 & 539 & 62.71 \\
\hline Pointe Ronde & 8.12 & 246 & 405 & 206 & 51 & 577 & 42.63 \\
\hline Picard & 12.41 & 382 & 501 & 262 & 52 & 807 & 47.34 \\
\hline Blenheim & 18.91 & 863 & 442 & 252 & 57 & 1126 & 76.64 \\
\hline Hampstead & 19.54 & 931 & 534 & 291 & 55 & 1155 & 80.61 \\
\hline Penton & 5.85 & 266 & 527 & 340 & 65 & 445 & 59.78 \\
\hline Mamelabou & 10.81 & 522 & 529 & 318 & 60 & 724 & 72.1 \\
\hline Woodford Hill & 5.59 & 240 & 585 & 368 & 63 & 430 & 55.81 \\
\hline Toulaman & 16.52 & 722 & 591 & 330 & 56 & 1012 & 71.34 \\
\hline Pagua & 38.11 & 1319 & 625 & 362 & 58 & 1959 & 67.33 \\
\hline Castle Bruce & 44.07 & 855 & 483 & 263 & 54 & 2197 & 38.92 \\
\hline St. Sauveur & 7.13 & 211 & 459 & 244 & 53 & 521 & 40.5 \\
\hline Rosalie & 29.87 & 987 & 494 & 272 & 55 & 1616 & 61.08 \\
\hline Toberi & 8.27 & 221 & 478 & 255 & 53 & 586 & 37.71 \\
\hline La Ronde & 3.20 & 88 & 468 & 247 & 53 & 276 & 31.88 \\
\hline Boetica & 2.23 & 75 & 499 & 274 & 55 & 208 & 36.06 \\
\hline Mulatre & 20.70 & 739 & 567 & 317 & 56 & 1209 & 61.12 \\
\hline Malabuka & 2.96 & 111 & 512 & 298 & 58 & 260 & 42.69 \\
\hline Geneva & 22.92 & 724 & 491 & 258 & 52 & 1311 & 55.23 \\
\hline Soufriere & 4.77 & 121 & 399 & 174 & 44 & 379 & 31.93 \\
\hline Gillon & 3.36 & 89 & 366 & 146 & 40 & 287 & 31.01 \\
\hline
\end{tabular}

